\title{
Kemapuan Berpikir Kreatif Ditinjau Dari Self Regulated Learning dengan Pendekatan Open-Ended Pada Model Pembelajaran Creative Problem Solving
}

\author{
Salahuddin Akbar Agus Panuntun Hsm¹, Mohammad Asikin', \\ Budi Waluya $^{1}$, Zaenuri ${ }^{1}$ \\ ${ }^{1}$ Universitas Negeri Semarang, Indonesia \\ *Corresponding email: salahuddinhsm95@gmail.com
}

Naskah diterima: 24 Januari 2021 | Disetujui: 30 April 2021 | Diterbitkan: 11 Mei 2021

\begin{abstract}
The ability to think creatively is very important to be developed in students, especially when learning is starting to shift to blended learning where students are required to be able to organize portions and also how to learn independently, for this reason, students in this era need to grow their creative abilities to be able to keep up with educational developments. This study aims to conduct studies related to factors that can foster creative thinking skills. The research method used in this study is the SLR (Systematic Literture Review) method. Data collection is done by collecting similar research articles and limiting it to the topic of mathematical creative thinking skills. The articles used in this study were 20 articles with the topic of creative thinking skills. Based on the literature review, the most influencing factors in creative thinking skills are problem-based models and open-ended approaches. For this reason, using the CPS model with an open-ended approach will provide a model with a new alternative approach that can be tried to improve creative thinking skills.
\end{abstract}

Keywords: creative thinking skills, CPS, open-ended SLR

\begin{abstract}
Abstrak
Kemampuan berpikir kreatif sangat penting dikembangkan pada diri siswa, terlebih lagi pembelajaran yang mulai beralih ke pembalajaran bleanded dimana siswa ditunutut agar mampu mengorganisir porsi dan juga cara belajar mereka secara mandiri. Untuk itulah siswa pada era ini perlu menumbuhkan kemampuan kreatifitas mereka agar mampu mengikuti perkembangan pendidikan. Penelitian ini bertujuan untuk melakukan kajian terkait dengan faktor yang dapat menumbuhkan kemampuan berpikir kreatif. Metode penelitian yang digunakan dalam penelitian ini adalah metode SLR (Systematic Literture Review). Pengumpulan data dilakukan dengan cara mengumpulkan artikel penelitian yang serupa dan membatasi pada topik kemampuan berpikir kreatif matematis. Artikel yang digunkan dalam penelitian ini sebanyak 20 artikel dengan topoik kemampuan berpikir kreatif. Berdasarkan kajian literature, faktor yang paling mempengaruhi dalam kemampuan berpikir kreatif adalah model yang berbasis dengan masalah dan juga pendekatan yang berbasis dengan open-ended. Oleh sebab itu, dengan menggunakan model CPS dengan pendekatan open-ended dapat menciptakan model dengan alternatif baru yang dapat dicoba untuk meningkatkan kemampuan berpikir kreataif.
\end{abstract}

Kata kunci: kemampuan berikir kreatif, CPS, open-ended SLR 


\section{Pendahuluan}

Di era moderenisasi teknologi yang semakin berkembang, masyarakat dituntut untuk mampu mengikuti dan beradaptasi dengan perubahan zaman, terlebih di masa pandemi covid-19. Setiap orang dituntut untuk merubah pola hidup mereka menuju ke normal baru atau biasa disebut dengan istilah new normal. Menurut Sigit dalam (Habibi, 2020) menyatakan bahwa new normal merupakan sebuah pola hidup baru yang dijalani oleh seseorang dalam melakukan aktivitas sehari-hari di tengah adanya pandemi covid-19. Dampak normal baru ini dirasakan oleh banyak sektor, salah satunya adalah sektor pendidikan.

Pendidikan Indonesia telah mengalami perubahan yang signifikan, yaitu beralihnya pembelajaran tatap muka menjadi pembelajaran daring, di mana siswa melakukan pembelajaran melalui jarak jauh. Menurut Mendikbud Nadiem Makarim (Kompasiana, 2021) pembelajaran tatap muka akan mulai diterapkan kembali secara serentak pada bulan Juli 2021 dengan mengombinasikan antara pembelajaran secara tatap muka dengan pembelajaran online. Oleh karena itu, perlunya guru dalam mempersiapkan pembelajaran yang mampu mengombinasikan antara pembelajaran tatap muka dengan pembelajaran online, atau yang biasa disebut dengan Blended Learning. Menurut (Wahyudi et al., 2020) dengan blended learning siswa mampu mencari informasi lebih luas baik melalui buku cetak ataupun informasi yang ada pada dunia maya. Sehingga guru sangat diperlukan dalam mengembangkan pembelajarn blended learning agar siswa mampu memperoleh pengetahuan yang lebih luas dan tidak hanya sebatas ruang kelas. Pembelajaran blended merupakan pembelajaran yang sangat sesuai untuk diterapkan pada situasi pandemi, dengan pembelajaran blended siswa dapat belajar secara madiri dengan memperoleh informasi dari berbagai sector, sehingga mampu menumbuhkan kemampuan berpikir kreatif siswa (Sari et al., 2021). Dengan pembelajaran belended siswa akan lebih mudah dalam mengonstruksi penyelesaian masalah dengan lebih baik kususnya pada mata pelajaran matematika, karena siswa tidak hanya memperoleh informasi dari guru, namun memperoleh informasi dari media masa dan media online.

Dalam menyelesaikan suatu masalah yang berkaitan dengan matematika diperlukan kemampuan berpikir matematis. Keterampilan berpikir matematis merupakan suatu proses berpikir yang melibatkan kemampuan mengumpulkan informasi baik secara deduktif maupun induktif, menganalisis informasi, dan melakukan generalisasi untuk mengembangkan pemahaman dan memperoleh pengetahuan baru (Nida et al., 2020). Keterampilan berpikir matematika diklasifikasian menjadi dua macam, yaitu keterampilan berpikir rendah (LOTS) dan keterampilan berpikir tinggi (HOTS) (Fajri, 2017).

Berdasarkan hasil penelitian oleh (Nida et al., 2020) hasil nilai rata-rata ujian nasional sekolah menengah pertama di Indonesia dua tahun terakhir (2017-2018) mengalami penurunan yaitu 48,65 (kategori D), dan sebesar 45,63 (kategori D). Penurunan ini disebabkan adanya peningkatan persentase butir soal dalam HOTS. Hasil ini secara tidak langsung menunjukkan bahwa rendahnya prestasi belajar matematis siswa Indonesia tingkat sekolah menengah pertama disebabkan oleh rendahnya kemampuan berpikir tingkat tinggi pada pembelajaran matematika. Dengan adanya masalah tersebut, salah satu keeterampilan berpikir HOTS yang perlu dikembangkan adalah kemampuan berpikir kreatif.

Berpikir kreatif membutuhkan imajinasi, kecerdasan, wawasan, dan gagasan tertentu sesuai dengan objek, masalah, dan kondisi yang sedang dihadapi. Salah satu cara yang dapat dilakukan untuk 
meningkatkan kemampuan berpikir kreatif adalah dengan menerapkan model CPS atau Creativity Problem Solving. CPS merupakan perpaduan yang sangat tepat bagi siswa untuk membantu keefektifan, kemandirian, dan tantangan kompleks yang sedang dihadapi siswa (Donald J. Treffinger, 2013). CPS merupakan salah satu model pembelajaran dengan proses penyelesaian masalah menggunaan teknik yang sistematis sehingga mampu memecakan masalah dengan cara mengumpulkan gagasan kreatif dari masalah yang dihadapinya.

Selain berpikir kreatif siswa, hal lain yang harus diperhatikan dalam pembelajaran adalah bagaimana cara siswa dalam mengelola pembelajaran mereka selama masa pembelajaran daring. Karena dalam masa pembelajaran daring siswa lebih terfokus dalam pembelajaran secara mandiri. Oleh sebab itu, guru perlu mengetahui kemampuan self-regulated learning siswa. Hal ini dilakukan untuk mengetahui bagaimanakah siswa mengonstruksi dan mengelola cara belajar mereka karena self-regulated learning tidak sepenuhnya dapat dimiliki oleh siswa. Berbagai kendala dan permasalahan kemampuan self-regulated learning masih menjadi fokus perhatian banyak pihak untuk menemukan solusi penelesaiannya (Handaka et al., 2019). Dalam penelitian (Handaka et al., 2019) menyatakan bahwa siswa yang tidak memiliki self-regulated learning akan memiliki strategi yang kurang baik dalam perencanaan belajar, strategi belajar yang buruk, motivasi belajar yang rendah, dan enggan dalam mengembangkan potensi diri. Oleh karena itu, kemampuan tersebut perlu diterapkan dalam diri siswa khususnya pada era pandemi, karena pada era ini siswa lebih banyak belajar di rumah tanpa ada pengawasan guru sebagai pengontrol belajar.

Berdasarkan uraian di atas, tujuan dari penelitian ini adalah untuk mengkaji kemapuan berpikir kreatif ditinjau dari self regulated learning dengan pendekatan open-ended pada model pembelajaran creative problem solving. Metode yang digunakan dalam penelitian ini adalah metode SLR (Systematic Literature Review), yaitu metode untuk mengidentifikasi, mengkaji, serta menafsirkan hasil temuan yang diperoleh oleh peneliti melalui jurnal-jurnal yang telah dikumpulkan berkaitan dengan kemampuan berpikir kreatif. Peneliti kemudian melakukan tinjauan dan mengidentifikasi seluruh jurnal secara sistematis sesuai dengan langkah-langkah yang ada pada SLR. Artikel yang digunakan dalam penelitian ini berjumlah 20 artikel yang diperoleh dari jurnal nasional dan juga internasional yang terindeks scopus, google scholar dan science direct. Setelah artikel berhasil dikumpulkan kemudian dianalisis dan dirangkum. Berikut merupakan data 20 artikel yang diperoleh peneliti.

Tabel 1 Sumber Refrensi Terkait dengan Pertanyaan Penelitian

\begin{tabular}{|l|l|}
\hline \multicolumn{1}{|c|}{ Fokus } & \multicolumn{1}{|c|}{ Sumber } \\
\hline $\begin{array}{l}\text { Faktor mempengaruhi } \\
\text { kemampauan berpikir kreatif }\end{array}$ & $\begin{array}{l}\text { (Alifiah, Y R, 2019); (Mukti \& Soedjoko, 2021); (Ferawati \& } \\
\text { (Marzuki, 2018); (Magelo et al., 2019); (Haq et al., 2020); } \\
\text { (Shoit \& Masrukan, 2021);Silviani, (Siviani et al., 2018); } \\
\text { (Tohir, 2019);(Widana \& Septiari, 2021) }\end{array}$ \\
\hline $\begin{array}{l}\text { Tentang Solusi metode dan } \\
\text { pendekatan yang cocok } \\
\begin{array}{l}\text { dengan berpikir kreatif } \\
\text { kaitan dengan blended }\end{array}\end{array}$ & $\begin{array}{l}\text { (Liu et al., 2017); (Noriza \& Waluya, 2020); (Newman et al., } \\
\text { al., 2018); (Setianingsih \& Purwoko, 2019); (Ulandari et al., } \\
\text { 2019); }\end{array}$ \\
\hline
\end{tabular}




\section{Hasil dan Pembahasan}

Data penelitian yang digunakan dalam kajian literature ini merupakan hasil dari rangkuman dan alternatif jawaban yang diperoleh dari artikel yang telah didokumentasi berkaitan dengan berpikir kreatif matematis.

Kemampuan berpikir kreatif merupakan kemampuan yang perlu dikembangkan pada diri siswa karena mampu mengembangkan kognitif, memori, dan kotrol yang menjadikan siswa mampu memunculkan ide-ide inovatif. Banyak peneliti yang mulai melakukan penelitian berkaitan dengan berpikir kreatif. Agar kemampuan berpikir kreatif matematis ini dapat ditanamkan pada siswa secara efektif, para peneliti mulai menggunakan model atau pendekatan yang cocok agar sesuai dan berdampak baik pada diri siswa. Seperti pada penelitian (Shoit \& Masrukan, 2021) untuk meningkatkan kemampuan berpikir kratif siswa peneliti menggunakan model problem posing, dari hasil penelitian ini menunjukan adanya peningkatan kemampuan berpikir kreatif setelah diberikan model tersebut. Terlihat bahwa kemampuan berpikir kreatif siswa level menengah ke atas menjadi lebih baik. Penelitian lainnya juga menunjukkan hasil yang sama, seperti pada penelitian oleh (Siviani et al., 2018) yang meneliti kemampuan berpikir kreatif dengan menggunakan model problem based learning, pada penelitiannya menunjukkan hasil yang cukup bagus dalam menigkatkan kemampuan berpikir kreatif meski tidak terlalu signifikan.

Dari dua penelitan di atas dapat disimpulkan bahwa penggunaan model pembelajaran mampu memberikan konstribusi yang baik dalam meningkatkan kemampuan berpikir kreatif, akan tetapi pemilihan dari model tersebut juga harus sesuai dengan karakteristik agar hasil yang diperoleh sesuai dengan tujuan dari penelitian yang ingin dicapai. Model pembelajaran berbasis masalah juga sangat cocok digunakan dalam menumbuhkan kreatifitas siswa. Selain dua penelitian dia atas, ada juga beberapa penelitian serupa yang menggunakan model berbasis masalah seperti pada penelitian (Ferawati \& Suhendri, 2020); (Widana et al., 2021) yang mengguakan PBL dalam meningkatkan kemampuan berpikir kratif.

Selain menggunakan model pembelajaran untuk meningkatkan kemampuan berpikir kreatif matematis, beberapa peneliti juga banyak menggunakan berbagai pendekatan agar kreativitas siswa dapat meningkat. Seperti pada penelitian (Alifiah, Y R, 2019); (Mukti \& Soedjoko, 2021) di mana kemampuan berpikir kreatif dapat ditingkatkan dengan menggunakan pendekatan open-ended. Hasil dari penelitian ini sangat signifikan dalam meningkatkan kreativitas siswa yang terindikasi bahwa pendekatakn open-ended merupakan pendekatan yang sangat baik dalam meningkatkan kemampuan siswa.

Kreativitas merupakan sebuah kemampuan dari seseorang untuk menemukan suatu inovasi baru dan bermanfaat (Zhuang et al., 2021). Menurut Ennis (Arifah \& Asikin, 2018) kemampuan berpikir kreatif adalah kemampuan suatu individu untuk menciptakan gagasan yang unik sehingga dapat digunakan dalam menyelesaikan suatu masalah bahkan hingga memunculkan alternatif baru dalam memecahkan masalah tersebut. Menurut (Benedenk \& Fink, 2019) berpikir kreatif adalah proses kompleks yang menggabungkan komponen perhatian, kontrol kognitif, dan memori. Berpikir kreatif juga merupakan kemampuan yang mampu mengaktifkan kapasitas yang belum pernah ada sebelumya untuk pemecahan masalah dan inovasi (Zhuang et al., 2021). Dari beberapa pendapat tersebut dapat disimpulkan bahwa kemampuan berpikir kreatif merupakan suatu kemampuan dari 
individu dalam memunculkan suatu ide baru atau potensi yang dihasilkan melalui sebuah inovasi yang belum pernah ada untuk memecahkan sebuah masalah.

Menurut (Rochmad et al., 2018) menyatakan bahwa kemampuan berpikir kratif meliputi beberapa aspek, yaitu kefasihan (fluency), fleksibilitas (fekxibility), originalitas (originality), dan elaborasi (elaboration). Aspek berpikir kreatif matematis menurut Pehkonen (Noriza \& Waluya, 2020) ada tiga, yaitu kelancaran, fleksibilitas, dan originalitas. Dalam penelitian (Wulandari, Ningsih, \& Putra. 2019) hanya menggunakan tiga aspek kemampuan berpikir kratif saja, yaitu (fluency, flexibility, dan originality) sehingga hasil dari penelitian ini memberikan keefektifan yang kurang maksimal, oleh sebab itu perlu dilakukan penelitian lanjutan yang mencakup seluruh apsek.

Studi empiris mengungkapkan bahwa Creativity Self-Efficay (CSE) dianggap sebagai salah satu aspek kreativitas individu (Puente-Díaz \& Cavazos-Arroyo, 2017); (Newman et al., 2018). Tidak hanya itu, penelitian ini juga menunjukan bahwa CSE mencakup kepercayaan diri dan kemampuan untuk mengambil keputusan yang memungkinkan individu menghadapi tantangan dan mencari solusi, sehingga mendorong tumbuhnya inovasi (Newman et al., 2018). Hal tersebut menunjukan bahwa CSE membutuhkan sebuah elaborasi (Newman et al., 2018). Adapun indikator-indikator dari tiap aspek menurut Treffinger (Tsaniyah \& Poedjiastoeti, 2017) adalah sebagai berikut:

Tabel 2: Indikator Kemampuan Berpikir Kreatifitas

\begin{tabular}{|c|c|}
\hline Aspek & Indikator \\
\hline $\begin{array}{l}\text { Kefasihan } \\
\text { (Fluency) }\end{array}$ & $\begin{array}{l}\text { 1. Mengidentifikasi masalah dari soal kedalam bentuk diketahui } \\
\text { dan ditanya. } \\
\text { 2. } \\
\text { 3. } \\
\text { Memunculkan ide jawaban yang sesuai atau relevan } \\
\text { Menjanyaan dengan lancer. }\end{array}$ \\
\hline $\begin{array}{l}\text { Fleksibilitas } \\
\text { (Fekxibility) }\end{array}$ & $\begin{array}{l}\text { 1. Menerapkan rumus secara tepat; } \\
\text { 2. } \quad \text { Memberikan alternatif jawaban melalui berbagai } \\
\text { pendekatan atau cara }\end{array}$ \\
\hline $\begin{array}{l}\text { Originalitas } \\
\text { (Originality) }\end{array}$ & $\begin{array}{l}\text { 1. Mengungkapkan penyelesaian dengan caranya sendiri atau } \\
\text { secara unik } \\
\text { 2. Memberikan penyelesaian yang berbeda pada umumnya atau } \\
\text { tidak lazim }\end{array}$ \\
\hline $\begin{array}{l}\text { Elaborasi } \\
\text { (Elaboration) }\end{array}$ & $\begin{array}{l}\text { 1. Memperinci detail-detail gagasan atau situasi untuk } \\
\text { memperoleh penyelesaian masalah; } \\
\text { 2. } \quad \text { Membuat suatu kesimpulan akhir/final. }\end{array}$ \\
\hline
\end{tabular}

Dari beberapa penelitian yang dilakukan oleh (Beaty et al., 2020); (Huang et al., 2020); (Zhuang et al., 2021), dilakukan di lapangan dengan treatment yang diberikan secara real time bersama subjek yang diteliti, hal ini bertujuan untuk meningkatkan kemampuan berpikir kreatif siswa yang masih rendah.

Dalam penerapan kegiatan pembelajaran online guru belum mampu secara real time menerapkan kemampua berpikir kreatif kepada siswa, namun demikian kemampuan berpikir kreatif juga perlu untuk dikembangkan dimasa pembelajaran daring. Pembelajaran yang dilakukan secara 
daring lebih menitikberatkan dalam mencari informasi dan solusi pada siswa, sehingga perlu adanya kreativitas yang dimiliki oleh mereka agar mampu menyelesaikan persoalan tanpa adanya dampingan dari orang lain. Hal ini dikarenakan kemampuan berpikir kreatif mampu mendorong untuk menumbuhkan inovasi (Newman et al., 2018).

Berdasarkan hasil review jurnal yang dilakukan (Siviani et al., 2018) walaupun model PBL yang digunkan dalam penelitian ini efektif dalam meingkatkan berpikir kreatif, namun peningkataknya hanya terjadi pada $50 \%$ siswa dari seluruh populasi. Pada penelitian (Shoit \& Masrukan, 2021) penggunaan model PBL memang memberikan hasil yang efetif dalam peningatan kemampuan berpikir kreatif, tapi yang meningkat hanya pada level menengah ke atas, sementara itu siswa pada level bawah masih kesulitan dalam mengidentifikasi masalah serta sulit menyelesaikan masalah dengan cara baru. Selain itu, pada penelitian (Setianingsih \& Purwoko, 2019); (Magelo et al., 2019) menyimpulkan bahwa masih diperlukannya sebuah model pembelajaran lain yang memuat karakteristik kemampuan berpikir kreatif sehingga kamampuan ini dapat diterapkan secara maksimal kepada siswa.

Creative Problem Solving adalah salah satu model pembelajaran menyelesaikan masalah menggunakan teknik sistematis dan mampu menemukan ide-ide yang kereatif (van Hooijdonk et al., 2020). Menurut Pucio (Arifah \& Asikin, 2018) CPS merupakan sebuah model yang memiliki fungsi meningkatkan proses berpikir siswa sehingga mampu membantu dalam memecahkan masalah maupun kesulitan yang dihadapi secara kreatif dan sistematis. Menurut Treffinger (van Hooijdonk et al., 2020) CPS memiliki tiga komponen utama, yaitu memahami permasalahan (understanding the challenge), menghasilkan ide (generating ides), dan mempersiapkan tindakan (preparing for action). CPS merupakan suatu model yang mampu meyiapkan siswa untuk mengutarakan banyak gagasan di setiap pemecahan masalah dan memunculkan berbagai jenis jawaban dalam setiap pertanyaan (fluency), memberikan kesempatan kepada siswa untuk menghasilkan gagasan dalam memecahkan suatu masalah, mampu melihat suatu konsep dengan cara yang berbeda, serta mampu menyajikan hasil dengan cara yang berbeda pula (felxibility) (Wasiran \& Andinasari, 2019). CPS juga memberikan kesepatan dalam memunculkan gagasan-gagasan baru bersifat unik yang dapat digunakan untuk memecahkan masalah serta menumbuhkan keratifitas dalam membuat penyelesaian yang tidak lazim (originality). Siswa juga diberi kesempatan dalam memperinci detail-detail gagasan atau situasi untuk memperoleh penyelesaian masalah sehingga mampu meningkatkan kualitas dari gagasan yang diperoleh siswa (elaboration).

Dalam pengembangan CPS terdapat beberapa landasan utama yang berkaitan dengan pelaksanaanya. Osborn dan Parnes mengemukakan enam kriteria CPS yang bisa disingkat dengan OFPISA yang meliputi Objective Finding, Fact Finding, Problem Finding, Idea Finding, Solution Finding, dan Acceptence Finding (Huda, 2014); (Kapoor et al., 2020). Dalam penerapannya model ini mampu mengembangkan kemampuan siswa dalam memecahkan masalah secara terbuka dengan berbagai representasi konsep. Tujuan dalam pembelajaran CPS adalah untuk memungkinkan siswa menghadapi peluang yang kompleks dan terbuka atau open-ended (Donald J. Treffinger, 2013)

Pendekatan open-ended merupakan salah satu pendekatan yang dapat digunakan dalam meningkatkan kemampuan berpikir kratif (Mukti \& Soedjoko, 2021). Berdasarkan hasil review, pendekatan open-ended merupakan pendekatan yang sangat cocok dalam meningkatkan berpikir 
kritis, hanya saja hasil yang diperoleh kurang maksimal dikarenakan model yang digunakan kurang tepat (Alifiah, Y R, 2019); (Huang et al., 2020).

Shimada (Faridah \& Aeni, 2016) meyatakan bahwa pembelajaran open-ended merupakan sebuah pendekatan yang mampu memunculkan beragam solusi untuk memecahkan suatu masalah. Aktamis dan Ergin (Demir \& Şahin, 2014) menyatakan bahwa soal open-ended dapat digunakan sebagai pengembangan kreativitas siswa. Karena sifatnya yang terbuka, maka dapat memberikan kesempatan bagi siswa untuk memperoleh tantangan dalam mencari solusi dan menemukan alternatif jawaban yang paling tepat. Terdapat beberapa tipe dari masalah open-ended. Pertama, penyelesaian dengan proses yang terbuka, yakni soal dapat diselesaikan dengan berbagai pendekatan/penyelesaian. Kedua, hasil akhir yang bersifat terbuka, yakni soal yang dibuat memiliki beragam jawaban yang tepat, sehingga tidak merujuk pada satu jawaban saja. Ketiga, pengembangan lanjutan yang bersifat terbuka, yakni siswa mampu mengembangkan soal/membuat soal baru dari masalah yang pernah diselesaikan dengan cara memodifikasi sayarat atau kondisi dari soal yang sedang diselesaikan.

Apabila dikaji lebih mendalam pendekatan open-ended miliki keterkaitan dengan model creative problem solving dalam meningkatkan kemampuan berpikir kreatif, keterkaitan dari ketiganya adalah sebagai beriut:

\section{a. Objective Finding}

Objective Finding yaitu upaya untuk mengidentifikasi situasi yang menyajikan tantangan berupa masalah. Pada tahap ini guru membagi kelompok secara divergen dan memberikan sebuah permasalahan yang bersifat terbuka (open-ended) yang dapat diselesaikan oleh siswa dengan bebagai macam metode penyelesaian. Pada tahap ini diberikan soal open-ended, hal ini berkaitan dengan salah satu aspek berpikir kratif matematis yaitu aspek fluency pada indikator pertama, dimana siswa mampu mengidentifikasi masalah dalam bentuk soal diketahui dan ditanya..

\section{b. Fact Finding}

Fact Finding yaitu upaya dalam mengenali seluruh fakta yang berkaitan dengan situasi yang sedang dihadapi serta mengenali hal-hal yang tidak diperlukam atau dibutuhkan. Pada tahap ini siswa mencoba menemukan fakta-fakta untuk mengonstruksi pola penyelesaian masalah yang dimilikinya. Guru mendaftar fakta-fakta yang ditemukan oleh siswa dan memberikan waktu kepada siswa untuk melakuakn revleksi dalam menemukan fakta mana saja yang paling relevan untuk menyelesaikan masasalah. Pada tahap fact finding berkaitan dengan aspek fluency pada indikator kedua dan ketiga, yaitu siswa mampu memunculkan ide jawaban yang sesuai atau relevan dan mampu menjawab pertanyaan dengan lancar.

\section{c. Problem Finding}

Problem Finding yaitu upaya mengenali seluruh perkiraan masalah yang terjadi dan memilahmilah masalah yang paling utama dari masalah yang telah diperoleh. Pada tahap ini siswa mendefinisikan seluruh permasalahan yang ada sesuai dengan topik agar siswa lebih dekat dengan masalah, kemudian siswa mulai memilah masalah yang memiliki karakteristik paling identik yang mampu memberikan dampak solusi paling tepat pada masalah yang sedang dicari. Pada tahap problem finding berkaitan dengan aspek flexibility pada indikator kedua, yaitu siswa mampu memberikan alternatif jawaban melalui berbagai pendekatan atau cara. 


\section{d. Idea Finding}

Idea Finding yaitu upaya dalam mengidentifikasi berbagai macam alternatif jawaban yang terjadi untuk digunakan sebagai pemecahan masalah. Pada tahap ini siswa mendaftar alternative jawaban sebanyak mungkin dari tahap problem finding sehingga memperoleh karakteristik alternatif jawaban yang sesuai dengan pemecahan masalah, hal ini dilakukan untuk melihat kemungkinan jawaban paling tepat yang akan dijadikan sebagai sebuah solusi penyelesaian. Setelah alternatif jawaban terkumpul, siswa diminta untuk memilih jawaban manakah yang paling sesuai untuk dijadikan sebagai sebuah solusi. Pada tahap ini, berkaitan dengan aspek flexibility pada inikator kedua dan ketiga, yaitu menerapkan rumus dengan tepat dan memberikan alternatif jawaban melalui cara yang beragam.

\section{e. Solution Finding}

Solution Finding yaitu upaya dalam menentukan kriteria menganalisa serta menetapkan kemungkinan-kemungkinan dari solusi jawaban. Pada tahap ini alternatif jawaban yang memiliki kemungkinan terbesar menjadi jawaban yang tepat akan dievaluasi dengan siswa atau kelompok, kemudian siswa merumuskan hasil jawaban dengan cara mereka sendiri. Pada tahap ini berkaitan dengan aspek keaslian pada indikator satu, yaitu mampu menuliskan penyelesaian dengan caranya mereka sendiri. Tahap solution finding juga berkaitan dengan aspek elaboration pada indikator pertama, yaitu mampu memperinci detail-detail gagasan atau situasi untuk memperoleh penyelesaian masalah.

\section{f. Acceptence Finding}

Acceptence Finding pada tahap acceptance finding siswa mulai merubah pola pikirnya dalam menghadapi permasalahan nyata yang terjadi dan memertimbangkan fakta yang harus digunakan dalam menyelesaikan masalah. Tahap ini diharapkan siswa mampu menyelesaikan masalah dengan cara mereka sendiri secara sistematis, kreatif, dan inovatif, baik dengan menggunakan cara baru atau mengombinasikan dengan berbagai fakta untuk menyelesaikannya. Pada tahap ini berkaitan dengan aspek elaboration pada indikator kedua, yaitu siswa dapat membuat suatu kesimpulan akhir atau final secara tepat dan akurat.

\section{Kesimpulan}

Model pembelajaran berbasis masalah merupakan model yang cocok dalam meningkatkan kemampuan berpikir keratif. Terdapat beberapa faktor yang mempengaruhi berpikir keratif, salah satunya adalah pendekatan berbasis open-ended. Hal tersebut dikarenakan sifat dari open-ended yang terbuka sehingga siswa dapat menyelesaikan permasalahan dengan cara mereka sendiri secara kreatif.

Dalam meningkatkan kemampuan berpikir keratif tentunya memerlukan model pembelajaran. Salah satu alternatif model yang dapat digunakan adalah model CPS. Hal tersebut dikarenakan karakteristik model CPS yang berbasis masalah, sehingga mampu digunakan dalam meningkatkan kemampuan beripkir kreatif. Selain itu model CPS dengan pendekatan open-ended akan memberikan dampak yang lebih besar dalam meningkatkan kemampuan berpikir kreatif, hal tersbut dikarenakan siswa dapat secara bebas menyelesaikan permasalahan yang terjadi dengan cara mereka sendiri secara kreatif. 


\section{Referensi}

Alifiah, Y R, \& K. I. (2019). Identifikasi tingkat berpikir kreatif siswa dalam memecahkan masalah open ended ditinjau dari gaya berpikir sternberg. Jurnal Ilmiah Pendidikan Matematika, 8(2).

Arifah, N., \& Asikin, M. (2018). Kemampuan Berpikir Kreatif Matematis Dalam Setting Pembelajaran Creative Problem Solving Dengan Pendekatan Open-Ended ( Sebuah Kajian Teoritik ). Program Studi Pendidikan Matematika, 441-446.

Beaty, R. E., Chen, Q., Christensen, A. P., Kenett, Y. N., Silvia, P. J., Benedek, M., \& Schacter, D. L. (2020). Default network contributions to episodic and semantic processing during divergent creative thinking: A representational similarity analysis. NeuroImage, 209(July 2019), 116499. https://doi.org/10.1016/j.neuroimage.2019.116499

Benedenk, M., \& Fink, A. (2019). Toward a neurocognitive framework of creative cognition: the role of memory, attention, and cognitive control. 27, 116-122.

Demir, S., \& Şahin, F. (2014). Assessment of Open-ended Questions Directed to Prospective Science Teachers in Terms of Scientific Creativity. Procedia - Social and Behavioral Sciences, 152, 692-697. https://doi.org/10.1016/j.sbspro.2014.09.264

Donald J. Treffinger, S. G. I. (2013). Teaching And Applying Creative Probelem Solving: Ipmlication For At-Risk Students. International Journal for Talent Development and Creativity. International Journal for Talent Development and Creativity, 1.

Fajri, M. (2017). Kemampuan Berpikir Matematis Dalam Konteks Pembelajaran Abad 21 Di Sekolah Dasar. Jurnal LEMMA, 3(1), 1-11. https://doi.org/10.22202/j1.2017.v3i1.1884

Faridah, N., \& Aeni, A. N. (2016). Pendekatan Open-Ended Untuk Meningkatkan Kemampuan Berpikir Kreatif Matematis Dan Kepercayaan Diri Siswa. Jurnal Pena Ilmiah, 1(1), 1061-1070. https://doi.org/10.23819/pi.v1i1.3025

Ferawati, F., \& Suhendri, H. (2020). Efektivitas Model Discovery Learning dan Problem Based Learning terhadap Berpikir Kreatif dan Kemampuan Pemecahan Masalah Matematika. JKPM (Jurnal Kajian Pendidikan Matematika), 6(1), 111. https://doi.org/10.30998/jkpm.v6i1.8311

Habibi, A. (2020). Normal Baru Pasca Covid-19. Adalah: Buletin Hukum dan Keadilan. 4.

Handaka, I. B., Saputra, W. N. E., \& Alhadi, S. (2019). Perbedaan self-regulated learning siswa SMP di Yogyakarta berdasarkan keberadaan kedua orang tua. Counsellia: Jurnal Bimbingan Dan Konseling, 9(1), 14. https://doi.org/10.25273/counsellia.v9i1.3416

Haq, I. M., Deniyanti, P., Pendidikan, M., Universitas, M., \& Jakarta, N. (2020). PENGARUH PEMBELAJARAN SEARCH SOLVE CREATE AND SHARE TERHADAP KEMAMPUAN BERPIKIR KREATIF. 13(4).

Huang, N. tang, Chang, Y. shan, \& Chou, C. hui. (2020). Effects of creative thinking, psychomotor skills, and creative self-efficacy on engineering design creativity. Thinking Skills and Creativity, 37(April), 100695. https://doi.org/10.1016/j.tsc.2020.100695

Huda, M. (2014). Model-Model Pengajaran dan Pembelajaran (Isu-Isu Metodis dan Paradigmatis). Pustaka Pelajar. 
Kapoor, N., Bansal, V. K., \& Jain, M. (2020). Development of creative problem solving-based framework for site planning in hill areas. Frontiers of Architectural Research, 9(2), 450-466. https://doi.org/10.1016/j.foar.2019.12.003

Kompasiana. (2021). https://nasional.tempo.co/read/1442557/konflik-demokrat-jokowi-mintamahfud-dan-yasonna-tak-memiha. ak.

Magelo, C., Hulukati, E., \& Djakaria, I. (2019). Pengaruh Model Pembelajaran Open-Ended terhadap Kemampuan Berpikir Kreatif Matematik Ditinjau dari Motivasi Belajar. Jambura Journal of Mathematics, 2(1), 15-21. https://doi.org/10.34312/jjom.v2i1.2593

Marzuki, D. I. (2018). Pengaruh Model Pembelajaran terhadap Kemampuan Berpikir Kreatif dan Kemampuan Komunikasi Matematika. Jurnal Pendidikan MIPA, 1(3), 235-241.

Mukti, A. A. B., \& Soedjoko, E. (2021). Kemampuan Siswa pada Aspek Berpikir Kreatif Ditinjau dari Gaya Belajar Melalui Pembelajaran Problem Posing Berbasis Open-Ended Problem. PRISMA, Prosiding Seminar Nasional $\quad \ldots, \quad 4, \quad 26-36$. https://journal.unnes.ac.id/sju/index.php/prisma/article/view/44955

Newman, A., Tse, H. H. M., Schwarz, G., \& Nielsen, I. (2018). The effects of employees' creative self-efficacy on innovative behavior: The role of entrepreneurial leadership. Journal of Business Research, 89(April), 1-9. https://doi.org/10.1016/j.jbusres.2018.04.001

Nida, N. K., Usodo, B., \& Sari Saputro, D. R. (2020). The blended learning with Whatsapp media on Mathematics creative thinking skills and math anxiety. Journal of Education and Learning (EduLearn), 14(2), 307-314. https://doi.org/10.11591/edulearn.v14i2.16233

Ningsih, E. F. (2019). Implementasi Model Pembelajaran Search, Solve, Create and Share (SSCS) untuk Meningkatkan Kemampuan Berpikir Kreatif Matematis. GAUSS: Jurnal Pendidikan Matematika, 2(1), 25. https://doi.org/10.30656/gauss.v2i1.1441

Noriza, D., \& Waluya, B. (2020). Kemampuan Berpikir Kreatif Matematis pada Tiap Gaya berpikir Gregorc. PRISMA, Prosiding Seminar Nasional Matematika, 3, 650-659.

Puente-Díaz, R., \& Cavazos-Arroyo, J. (2017). The influence of creative mindsets on achievement goals, enjoyment, creative self-efficacy and performance among business students. Thinking Skills and Creativity, 24, 1-11. https://doi.org/10.1016/j.tsc.2017.02.007

Rochmad, Agoestanto, A., \& Kharis, M. (2018). Characteristic of critical and creative thinking of students of mathematics education study program. Journal of Physics: Conference Series, 983(1). https://doi.org/10.1088/1742-6596/983/1/012076

Sari, P. R., Tusyantari, N. B., \& Suswandari, M. (2021). DAMPAK PEMBELAJARAN DARING BAGI SISWA SEKOLAH DASAR SELAMA SELAMA COVID-19 Universitas Veteran Bangun Nusantara, Sukoharjo. Prima Magistra: Jurnal Ilmiah Kependidikan, 2(1), 9-15.

Setianingsih, L., \& Purwoko, R. Y. (2019). Kemampuan Berpikir Kreatif Siswa SMP dalam Menyelesaikan Soal Open-Ended. Jurnal Review Pembelajaran Matematika, 4(2), 143-156. https://doi.org/10.15642/jrpm.2019.4.2.143-156

Shoit, A., \& Masrukan, M. (2021). Kemampuan Berpikir Kreatif Siswa Ditinjau dari Rasa Ingin Tahu pada Pembelajaran Problem Posing Berbasis Open Ended Problem dengan Performance Assessment. PRISMA, Prosiding Seminar Nasional Matematika, 4, 37-48. 
Siviani, R., Zubainur, C. M., \& Subianto, M. (2018). Kemampuan Berpikir Kreatif Siswa SMP melalui Model Problem Based Learning. Jurnal Didaktik Matematika, 5(1), 27-39. https://doi.org/10.24815/jdm.v5i1.10125

Tohir, M. (2019). Keterampilan Berpikir Kreatif Siswa Dalam Menyelesaikan Soal Olimpiade Matematika Berdasarkan Level Metakognisi. Alifmatika: Jurnal Pendidikan Dan Pembelajaran Matematika, 1(1), 1-14. https://doi.org/10.35316/alifmatika.2019.v1i1.1-14

Tsaniyah, A. B., \& Poedjiastoeti, S. (2017). Moge Learning Model To Improve Creative Thinking Skills. International Journal of Education and Research, 5(1), 165-172.

Ulandari, N., Putri, R., Ningsih, F., \& Putra, A. (2019). Efektivitas Model Pembelajaran Inquiry terhadap Kemampuan Berpikir Kreatif Siswa pada Materi Teorema Pythagoras. Jurnal Cendekia: Jurnal Pendidikan Matematika, 3(2), 227-237. https://doi.org/10.31004/cendekia.v3i2.99

van Hooijdonk, M., Mainhard, T., Kroesbergen, E. H., \& van Tartwijk, J. (2020). Creative Problem Solving in Primary Education: Exploring the Role of Fact Finding, Problem Finding, and Solution Finding across Tasks. Thinking Skills and Creativity, 37(May), 100665. https://doi.org/10.1016/j.tsc.2020.100665

Wahyudi, W., Waluya, S. B., Suyitno, H., \& Isnarto, I. (2020). The impact of 3CM model within blended learning to enhance students' creative thinking ability. Journal of Technology and Science Education, 10(1), 32-46. https://doi.org/10.3926/jotse.588

Wasiran, Y., \& Andinasari, A. (2019). Meningkatkan Kemampuan Berpikir Kreatif dan Penalaran Adaptif Matematika Melalui Paket Instruksional Berbasis Creative Problem Solving. JNPM (Jurnal Nasional Pendidikan Matematika), 3(1), 51. https://doi.org/10.33603/jnpm.v3i1.1466

Widana, I. W., \& Septiari, K. L. (2021). Kemampuan Berpikir Kreatif dan Hasil Belajar Matematika Siswa Menggunakan Model Pembelajaran Project-Based Learning Berbasis Pendekatan STEM. Jurnal Elemen, 7(1), 209-220. https://doi.org/10.29408/jel.v7i1.3031

Zhuang, K., Yang, W., Li, Y., Zhang, J., Chen, Q., Meng, J., Wei, D., Sun, J., He, L., Mao, Y., Wang, X., Vatansever, D., \& Qiu, J. (2021). Connectome-based evidence for creative thinking as an emergent property of ordinary cognitive operations. Neurolmage, 227. https://doi.org/10.1016/j.neuroimage.2020.117632 
Kemampuan Berpikir Kreatif Ditinjau Dari Self Regulated Learning dengan Pendekatan Open-Ended Pada... Salahuddin Akbar Agus Panuntun, Mohammad Asikin, Budi Waluya, Zaenuri 